\title{
Communicating a Social Agenda within HEIs: The Role of the Social Enterprise Mark
}

by

Emma Sutton, Morven G. McEachern and Kevin Kane

Emma Sutton and Dr Kevin Kane

Salford Business School

University of Salford

The Crescent

Salford,

M5 4WT

Professor Morven McEachern*

Huddersfield Business School,

University of Huddersfield,

Queensgate,

Huddersfield,

HD1 3DH.

m.mceachern@hud.ac.uk

*Author for correspondence.

Article classification: Research paper

Conflict of interest: There is no potential conflict of interest in this research.

Acknowledgements: We would like to thank the anonymous comments and suggestions made by our reviewers. 


\title{
Communicating a Social Agenda within HEIs: The Role of the Social Enterprise Mark
}

\author{
Structured Abstract \\ Purpose \\ Using the lens of the Social Enterprise Mark (SEM) accreditation which enables social \\ enterprises to 'prove' that the interests of people and planet are put before shareholder gain, this \\ study sought to enhance our knowledge of how effectively the social agenda is communicated by \\ Higher Education Institutions (HEIs). \\ Design/methodology/approach \\ Using a qualitative research design, this exploratory study uses a combination of both a focus \\ group and in-depth interviews with HEI holders of the SEM.
}

Findings

With a particular focus on University A, this study advances our knowledge around how social agendas and the role of the SEM in particular, are used to communicate to HEI employees as a key stakeholder group.

\section{Research Limitations}

At the time of this study, fewer SEM accredited HEIs existed and therefore, the following conclusions are based upon a small select sample of HEIs that held the SEM. Further studies are needed to provide a more representative view of each University's use of and commitment to the SEM/SEGM.

\section{Practical/Social limitations/implications}

Building on Powell \& Osborne's (2015) observations regarding the role of marketing in social enterprises, the findings of this study offer practical insight to current and/or prospective HEI SEM holders as to the role of 'social' accreditations; stakeholder perceptions of such marketing initiatives; and how they can be used effectively as a vehicle to improve social communications in the future.

\section{Originality/value}

The area of social enterprise and social impact has been evolving in recent decades, but academic studies in relation to the promotion and communication of certification schemes such as the SEM in the higher education sector remains scant. This study responds to this gap in the literature by providing greater insight into how social agendas and engagement with the SEM specifically, are communicated by HEIs.

Keywords: Higher education; Social enterprise mark; Social value; Social enterprise; Social impact reporting; Marketing communications. 


\section{Introduction}

Despite extensive literature around the conceptualisation of social enterprise in the UK (see for example Haugh, 2005; Domenico et al., 2009; Galera \& Borzaga, 2009; Teasdale, 2010;

Mauksch et al., 2017), Higher Education Institutions (HEIs) are increasingly recognised as social enterprises ${ }^{1}$ in their own right, whilst simultaneously striving to develop and promote links with other social enterprises in order to demonstrate social impact and enhance competitive advantage (Allan, 2005; Brown, 2015; Social Enterprise Mark, 2018). Moreover, the dual purpose "hybrid" (see Doherty et al., 2014) nature of HEIs (i.e. pursuing a mixture of social objectives and profitmaking objectives) has meant that they are considered by many to be the natural successor to cash-strapped local authorities, given that they possess both the available resources and the requisite public commitment to the local community to engage effectively (Thompson, 2011; Mannion, 2016). However, evidence suggests that there remains a lack of awareness among HEI stakeholders about current initiatives within their institutions to advance a social agenda (Djordjevic \& Cotton, 2011; Lozano, 2011). Although a number of certification schemes have been developed in recent years (e.g. the Social Enterprise Mark (SEM); B Corporation certification; and Social Enterprise UK), the challenge for HEIs is to identify a meaningful approach to measuring and communicating social value to stakeholders (Kickul \& Lyons, 2012; British Council, 2016).

The SEM is an accreditation scheme that promotes enterprises that use their profits to maximise social and/or environmental impact across a range of sectors (Ridley-Duff \& Bull, 2016; Social Enterprise Mark, 2018). It can also be used as a vehicle for enterprises to improve

\footnotetext{
${ }^{1}$ Although regarded as highly complex and often contested, a common definition of social enterprise is an "independent organisation with social and economic objectives that aims to fulfil a social purpose as well as achieving financial stability through trading" (Haugh, 2005, p3). In other words, social enterprise "shapes, and is being shaped, through everyday practice", and therefore, understood as an ongoing "performative enactment" (Mauksch et al., 2017, p.114).
} 
their credibility as social enterprises and to set themselves apart from competitors as an ethical alternative (Social Enterprise Mark, 2018). The SEM also aids strategic differentiation as it prevents private businesses from "claiming they are social enterprises on the basis of their PR and community-support activities" (Ridley-Duff \& Southcombe, 2012, p.179). Building on Ridley-Duff and Southcombe's (2012) critical review of the conceptual dimensions of the SEM, the guiding research question for this paper is whether the SEM accreditation provides HEIs with a tool to positively influence communication of their social message to stakeholders, or whether it pays lip service to their commitment to a social agenda?

Consequently, there is scope to empirically advance our understanding of social value creation in HEIs, borne out by the fact that eleven UK universities have already been accredited by the SEM (Djordjevic \& Cotton, 2011; Social Enterprise Mark, 2018). Despite the evergrowing body of literature on social enterprise in general (Defourny \& Nyssens, 2008; Perez de Mendiguren Castresana, 2013; Kay et al., 2016), little has been published regarding its engagement with the higher education sector (British Council, 2016). Therefore, this study aims to contribute to the social enterprise field by investigating the effectiveness of the SEM as a communication tool for HEI employees. Thus, advancing our knowledge of how the social agenda is currently being communicated to key HEI stakeholder groups, namely employees, with a particular focus on University A.

In light of the growing number of international, socially-led, ethics-led and/or sustainability-led accreditations available to HEIs (e.g. Ashoka ${ }^{2}, \mathrm{PRME}^{3}$ ), the importance of

\footnotetext{
${ }^{2}$ Ashoka is a network which aims to address global problems. In so doing, they "identify and accelerate cutting edge social innovation", aiming to bring together communities to help build a world where "everyone is equipped and empowered to be a changemaker" (Ashoka, 2018).
} 
further research into stakeholder and community engagement in the HEI reporting process is strongly accentuated (Schmeltz, 2012; Ceulemans et al., 2015; Too \& Bajracharya, 2015). Regarding the role of marketing in social enterprises, of which securing various accreditations plays a key part, Powell \& Osborne (2015) also acknowledge the limited understanding of such activities within social enterprises. Thus, in response to such calls and to advance our knowledge around the role of the SEM accreditation scheme when pursuing a social agenda, the following objectives are identified for this paper. First, we explore what University A's employees understand by a social agenda and how it is communicated; Next, we seek to understand how University A currently uses its SEM status to communicate its social values; and finally, we critically compare how University A's approach compares with that of four other HEIs holding the SEM.

This paper first considers the empirical literature which begins by reviewing the characteristics of the SEM and its accreditation process. Next, within the context of the SEM, we explore the communication of a social agenda within HEIs, with specific emphasis on communication and stakeholder management, to better understand how the social message can be communicated. After an outline of the adopted methodology, key findings, discussion and conclusions sections are then presented.

\section{Characteristics of the Social Enterprise Mark: A Communications Perspective}

The process of SEM accreditation involves defining the HEI as a social enterprise and is based on conformity with six criteria relating to the HEIs social/environmental objectives and the

\footnotetext{
${ }^{3}$ The Principles for Responsible Management Education (PRME) is a United Nations-supported initiative founded in 2007 as a platform to raise the profile of sustainability in schools around the world, and to equip today's business students with the understanding and ability to deliver change tomorrow (PRME, 2018).
} 
distribution of its profits for social/environmental purposes. Consequently, a stringent registration process is undertaken to assess applications in terms of suitability, with some $30 \%$ of all applications or expressions of interest rejected on ineligibility grounds (Ridley-Duff \& Bull, 2016; Social Enterprise Mark, 2018). In view of the excluded organisational formats, this has drawn much academic criticism. For example, a company limited by shares such as ethical market leader Café Direct, would not be eligible to become accredited by the SEM (see Westall, 2009). Others' note SEM's evaluation criteria as being biased in favour of charities (i.e. HEIs are generally deemed 'exempt charities') and community interest companies (CICs), as they exclude: co-operatives who pay over $50 \%$ of their profits as dividends to members; enterprises who earn less than $50 \%$ of their income via trading; and enterprises who have no "asset lock to prevent assets being used for private gain" (Teasdale, 2010, p.14; Ridley-Duff \& Southcombe, 2012). Nonetheless, the SEM currently feature 11 UK-based HEIs and just under 200 accredited social enterprise members, less than ten of which are international (Social Enterprise Mark, 2018). This is in contrast to the likes of Ashoka and PRME who feature 45 HEI members across nine countries and over 600 signatories across 100 countries (see Ashoka, 2018 and PRME, 2018 respectively).

As is common practice amongst many accreditation bodies, there are also tiered levels of membership (e.g. PRME has a Basic Signatory, Advanced Signatory and PRME Champion level). In the context of the SEM, eligible enterprises demonstrating robust governance, good business practice and ethics, as well as social impact and financial transparency, leads to an enhanced accreditation membership in the form of the Social Enterprise Gold Mark (SEGM), of which five HEIs have achieved 'social enterprise excellence' to date (Social Enterprise Mark, 2018), one of which includes University A. With the aim of guaranteeing such standards to an 
external audience, basic/enhanced membership of SEM enables HEIs to use a specific logo (see Social Enterprise Mark, 2018) in their corporate communications and access a range of on-line promotional resources.

Since time immemorial, the HEI sector has sought external validation of its governance, research and educational programmes to claim elements of international quality (e.g. Research Excellence Framework $^{4}$ (REF) and the Knowledge Exchange Framework ${ }^{5}$ (KEF)). With benefits and impacts identified as including enhanced institutional reputation, knowledge mobilisation, learning opportunities for students and a greater understanding of societal needs, alongside the opportunity to empower both SE partners and local communities (The British Council, 2016), HEIs and social enterprises are increasingly engaging with local communities to address social problems, improve efficiency measures and increase stakeholder involvement (Lozano et al., 2015). Hoefer and Sliva (2016) argue that a core motivation for such behaviour is that the funding challenges facing HEIs are similar to those of non-profit companies, therefore requiring them to look to new models to enhance their services and funding sources by extending their mission to include the local community. This adds further support for UK HEIs to use accreditations such as the SEM to provide evidence of social value that benefits both institution and community. Due to the plethora of accreditations however, this in itself causes problems for HEIs. Namely, the lack of standardisation in assessment tools across institutions, make it extremely difficult to generalise findings (Shriberg, 2002). Peattie and Morley (2008, p.102) also add that the very "hybrid" nature of HEIs as a social enterprise makes them particularly “challenging businesses to manage, to research and to develop effective policies for". More

\footnotetext{
${ }^{4}$ The REF is the UK's system for assessing the excellence of research in HEIs.

${ }^{5}$ The KEF is intended to increase HEI efficiency and effectiveness in use of public funding for knowledge exchange.
} 
importantly, the majority of University accreditations refer to 'sustainability' in a very general way (Lozano et al., 2015), with limited or no specific focus on a social agenda per se.

Therefore, additional professional accreditations such as the SEM can help to provide credibility and legitimacy to HEIs seeking to improve their social and environmental credentials. However, Allan (2005) points out that any additional accreditation must offer something of value to communities to ensure that it does not simply become another in a long line of similar accreditations. While some would suggest that the SEM has been successful in attracting membership (Ridley-Duff \& Southcombe, 2012), the jury is still out as to whether it offers something different from other social enterprise schemes such as Social Enterprise $\mathrm{UK}^{6}$ or established sustainable and/or socially-responsible accreditations such as PRME and Ashoka.

The official SEM website offers information on the history of the accreditation, the qualification criteria and application process, benefits and resources available to SEM holders, as well as access to a Directory of Accredited Social Enterprises providing details on individual holders, together with their social impact declarations (Social Enterprise Mark, 2018). Although there are more than 150 metrics available for assessing social impact (Murray et al., 2010), Moody et al. (2015) argue that none have become widespread among social enterprises/HEIs owing to the complexities of calculating social value.

In fact, much of the communications research generalises about communication in organisations without specifically addressing how this may be structured differently within the public, private and third sectors: for example, Goodman (1994) merely reflects that the way in

\footnotetext{
${ }^{6}$ With over 1000 members, Social Enterprise UK (SEUK) is one of the largest social enterprise networks whose work involves communicating the concerns of members and ensuring social enterprise issues are heard by decision makers across sectors. They also carry out leading research to build the evidence base for social enterprises. They also have a strong regional presence in communities through a Social Enterprise Places Programme (SEUK, 2017).
} 
which organisations communicate depends on the character of the organisation and its relationship with its stakeholders. As a result, Varey and White (2000) advocate the need for stronger links between those who need to communicate and senior management who are responsible for facilitating these communications. Barrett (2002) and Thornhill et al. (1996) support this proposition, stating that employee communication is pivotal in organisational strategies that promote employee involvement and commitment, including initiatives to increase information flow up and down the organisation, thereby emphasising the importance of strategic employee communications (see also Thornhill et al., 1996; Melewar \& Akel, 2005).

Organisational structure is believed to play a decisive role in how communication management becomes institutionalised and legitimised, both formally and informally (Grandien \& Johansson, 2012; Gunter et al., 2012). Here, Goodman (1994) asserts that many corporations consolidate their communications centrally in order to project a uniform image and maintain the culture of the organisation through consistent and coherent use of messages. This approach is generally supported in that internal communication is aimed at promoting organisational goals and reinforcing employee commitment, particularly during periods of change, affirming the need for upwards and downwards communication to ensure employees commit to the change (Barrett, 2002; Cornelissen, 2008; Welch, 2011).

It is noteworthy that the concept of organisational legitimacy, both internally and externally, is one that appears repeatedly throughout the communication literature (Cornelissen, 2004; Grandien \& Johansson, 2012). This logic clearly applies to employees as stakeholders, because their perceptions of their organisation's integrity will be negative if there is no consistent message between what is being instructed by senior management and what is being projected to 
the marketplace. This is further evidenced by Cornelissen (2008), who suggests that internal communication can only be effective if employees are well informed about the future direction of the organisation.

As stakeholder identity and image are central to managing communication in HEIs (Kantanen, 2012), Djordjevic and Cotton (2011) point to some of the common weaknesses inherent in HEI communications, namely the failure of awareness-raising campaigns to make a difference in employee behaviour; information overload resulting in incoming e-mail traffic being widely ignored; and the reluctance of employees to decode messages. Consequently, many authors (Schmeltz, 2012; Ceulemans et al., 2015; Too \& Bajracharya, 2015) emphasise the importance of further research into stakeholder and community engagement in the HEI reporting

process. In the absence of earlier work around HEIs and engagement with social enterprise-based accreditations, an interesting research question which this current study seeks to address, namely does the SEM accreditation provide HEIs with a tool to positively influence communication of their social message to stakeholders, or does it simply pay lip service to their commitment to a social agenda?

\section{Adopted Methodology}

Leaning towards a social constructionist approach (Easterby-Smith et al., 2002); a qualitative research design was selected, making use of both a focus group and semi-structured interviews to actively create data. An informal telephone interview was also held with the Social Enterprise Mark CIC marketing team prior to data collection in order to provide insights into the 
organisation's promotional activity around the SEM and to inform the line of questioning in the focus group and interviews.

Data collection was carried out in two stages: (1) an exploratory focus group involving participants from University A; (2) a series of face-to-face and telephone depth interviews with selected participants from University A and all other SEM/SEGM HEI members at the time of the research. These methods were preferred to survey research, because of the flexibility in questioning and the opportunity to direct conversation in order to draw out experiences, whilst maintaining consistency over the concepts discussed (Wengraf, 2001; Kozinets et al., 2013).

The focus group took place at University A. While twelve potential participants were approached via e-mail or phone, only six individuals were ultimately able to participate. However, there was considered to be good representation across the University's divisions (i.e. participants from the Library, Estates, Research \& Enterprise, relevant research Centres and the Business School Marketing team), thus, providing a range of perspectives capable of revealing insight and contradictions in the SEM discourse. The discussion was wide-ranging and lasted one hour, punctuated with visual stimuli, such as an SEGM leaflet, University A's social and economic impact report and a short social impact video to direct attention to the study's main focuses of interest. This sought to draw out views that would provide rich information with which to inform areas of discussion when conducting the subsequent interviews (Kozinets et al., 2013).

The second stage comprised a series of semi-structured interviews, with primary data collected either face-to-face or via telephone interview with the principal SEM contacts at each HEI. It was concluded that conducting depth interviews of this kind would capture personal 
perspectives and experiences with the SEM (Wengraf, 2001) as well as provide significant insight into how these institutions could more effectively use this as a communication tool. However, it should be noted that, although a similar set of questions was asked at each interview, responses varied in length and depth, with the face-to-face interviews at University A, generally provoking more open and naturally flowing conversation.

A purposive sampling technique was used to select participants, whereby informationrich participants able to specifically address the research problem posed were deliberately selected in order to provide greater insights and perspectives (Patton, 2002; Silverman, 2013). When recruiting for the focus group at University A, consideration was given to the general recommendation that groups comprise between six and eight people, usually sharing a particular characteristic (Kozinets et al., 2013; Silverman, 2013). Silverman (2013) proposes giving consideration to how many interviews will be sufficient when using a semi-structured interview format. Largely owing to time and resource constraints, the number of interviews was restricted to seven: three at University A, which forms the primary focus of this study, and one from four other HEIs holding the SEM/SEGM.

Based on the focus group data gathered and with further reference to the literature review, a more comprehensive and tightly-focused discussion guide was subsequently developed for the key-participant interviews, concentrating primarily on respondents' views on social enterprise, measurement of social and environmental impact and the way in which the SEM is promoted and communicated in their institution with guidance from Social Enterprise Mark CIC. A list of discussion points was sent to the participants in advance for preparation purposes. 
Consequently, the focus group and interviews collected over a 7-week period in 2016-17 were audio-recorded and transcribed verbatim following each meeting with participants' consent. Drawing on Attride-Sterling's (2001) thematic analysis tool, thematic networks were constructed, whereby basic themes were rearranged into organising themes, refined into further themes until saturation was reached and in a final stage, global themes were deduced (Braun \& Clarke, 2006; Silverman, 2011). An example of this process is shown in Table 1. The focus group discussion involving University A's employees' understanding of a social agenda and how it is communicated illustrated two global themes which emerged abductively as a result of the transcript analysis: (1) Poor employee engagement with the social agenda; and (2) Greater institutional commitment needed to drive social engagement. The interview data focuses on how University A currently uses its SEGM status to communicate its social values and compares these activities with that of four other HEIs holding the SEM/SEGM. Here, four major themes emerged inductively: (1) commitment to a social agenda; (2) reporting social impact; (3) engaging the student body; and (4) embedding the social agenda within HEIs. In light of publication restrictions, it is necessary to remain succinct and avoid repetition, therefore, the following findings are presented under the broad headings of: (1) Employee perceptions and engagement with the SEM; (2) Observations of HEIs and their commitment to a social agenda; and (3) HEI communication practices when conveying a social agenda. Credibility and trustworthiness of the findings was verified through triangulation of the focus group data with the interview data for corroboration purposes, as well as through achievement of rich data gathered through use of active listening techniques (Silverman, 2011). 
Descriptors have been used to conceal the identities of each respondent and their institution in order to ensure that data used cannot be linked back to any individual (see Table 2 for details of key-participant descriptors used for the sample).

Insert Tables 1 and 2 near here

\section{Employee Perceptions and Engagement with the SEM}

Unless directly involved with the accreditation (i.e. central to the individual's role within the HEI), University A's employees possessed little awareness of the SEM and its accreditation process. In fact, when discussing the various accreditations that University A held, it quickly became apparent that employees generally struggled to name any of the widely recognised accreditations (e.g. Business in the Community, Athena SWAN, and The Small Business Charter). Part of the explanation offered for their lack of awareness and/or knowledge, was due to the fact that the University promoted a wide variety of accreditations, for example: "I know the School's got lots, but I don't know what they are. They're just an alphabet soup of letters aren't they?" (FG P1). Another explanation for employees' limited awareness and/or understanding of the SEM was that they were often too busy to engage with many of the mass communications received:

“I think sometimes just mass-e-mailing people just to say you've communicated doesn't mean its message has actually been reached or achieved or, you know, so I think the way it's communicated could be looked at" (FG P3);

"Yes, communication is two-way, so it's also communication, communicating centrally, but it's people taking that message on board or taking it out and looking or being engaged” (FG P5). 
These findings complement Djordjevic and Cotton's (2011) study, which suggests that employees suffer from information overload and as a result generally ignore mass e-mails, because they are unwilling and/or unable to spend time decoding the messages. For the SEM specifically, there was also a general lack of awareness across each of the accredited Universities around what 'social enterprise' meant and whether it should apply to HEIs, for example:

\footnotetext{
"I'm conscious that every time that social enterprise is discussed, whenever I watch them discuss it in mainstream media, it always starts with an explanation of what they are” (FG P1);

“One gets quite fed up, actually, with going over this - what is a social enterprise”? (HEI 4).
}

After discussing the concept of social enterprise, many employees agreed that the University has a civic duty to become a driver for engagement with social enterprise, for example one participant felt that "The University is part of the infrastructure of the State and when you break it down, the University is one of the fundamental pillars of, you know, a civil society" (FG P1). The current fee-paying structure was another aspect of HEI business that confirmed HEIs as social enterprises by the majority of participants:

\footnotetext{
"Because I think it's a business. I think it's obviously allowed to be - it's a public sector organisation, but when I look at my understanding of a social enterprise, it can make troughs of money, it's what it does with that money" (HEI 1C);

"I have difficulty with the notion of universities as businesses, but I do recognise for all sorts of reasons why to call ourselves a social enterprise has got a certain amount of growing understanding within the sector" (HEI 2).
} 
These "hybrid" (see Peattie \& Morley, 2008; Doherty et al., 2014) perceptions are also supported in the social enterprise literature, which indicates that HEIs are increasingly being recognised as social enterprises in their own right and employees are therefore encouraged to engage further with local social enterprises to demonstrate social impact (Allan, 2005; Brown, 2015; Mannion, 2016). However, a common response to senior management requests for greater employee engagement with the SEM and the social agenda in general, was often perceived as a coercive attempt to make employees engage beyond that of their core work activities and in some cases, perceived as a way to force employees into being social:

\footnotetext{
"We are supposed to get the time to engage more in these things, but the nature of the University is that we're all busy. And at the end of the day, you've got to get your job done and if you've got all this stuff on top, something's got to give somewhere" (FG P6);

“...so why should I give here any more or less than giving near my own home or community, or to a particular charity or cause, so it's very much a personal thing, isn't it? (...) It shouldn't be forced through your workplace" (FG P4).
}

Consequently, it emerged that engagement with the SEM and/or a social agenda fluctuated greatly, both at individual and institutional level. This is further reinforced by Djordjevic and Cotton's (2011) study, who conclude that attempts to change employee behaviour and increase involvement in social activity are futile and almost always, generally fail. This outcome is not specific to HEIs but to all corporate settings, thus creating numerous calls for a more 'cooperative university' (Winn, 2015, p.40).

\section{Observations of HEIs and their Commitment to a Social Agenda}


Certainly for some participants, the core business of an HEI was to focus on recruiting students rather than the pursuit of a social agenda: “And if people's concerns are the immediate, you know, getting student numbers and validating new degrees which will attract more students in the future, the day-to-day concerns sometimes eclipse any high-minded values" (HEI 2).This led to the expression of scepticism towards the benefits of SEM membership and/or the pursuit of a social agenda for both the HEI and the student population:

\footnotetext{
"I don't think a student will go "Oh, we've got a Gold Mark in social enterprise. I must go there, because I will get a fantastic career out of it” (FG P4);

"You know, universities are increasingly measured on where students end up (...). You know, that's part of the DLHE [Destination of Leavers from Higher Education] survey, that's the test it's linked to. Therefore pushing, encouraging students to go and work in sectors that are low paid is not in the University's financial interests at all" (FG P1).
}

It was felt that these tensions highlighted a disconnect between HEI levels of commitment and subsequent management/employee engagement with SEM and a social agenda in more general and as a result, several participants felt that their respective institution lacked a centralised social strategy:

\footnotetext{
"I think it's done a little bit piecemeal. I don't think it's quite as joined up as perhaps we would like it to be" (HEI 1B);

"Even if you have a leader who is very clear with their values and their views and the direction they'd like to go in, the speed at which they go and the direction which they take, they've got to take everybody else with them" (HEI 2);
}

This disconnect was seen by many as a direct lack of funding, for example one participant stated that: "universities like badges and they like making statements, but they don't like putting large resources behind it" (HEI 1A). Other participants explained that their HEI approach to implementing a social agenda appeared fragmented and tokenistic due to the fact that so many 
additional socially-led initiatives such as PRME or Business in the Community were also embraced by HEIs to help communicate their social agenda. Another participant felt that the disconnect experienced by employees was due to a lack of commitment from senior management and that it was not always possible to obtain the necessary commitment to the social element, for example:

\footnotetext{
"We're not at that stage yet, I mean, there are people who can do this internally, put it that way. That might not be the best way to do it, but, you know, I haven't yet got the buy-in" (HEI 5);

"I wouldn't say the commitment isn't there, but it's not seen as something we spend a long time communicating about” (FG P1);

"I think the people that are driving social enterprise buy-in and most HEIs tend to be relatively down the ladder, rather than being very senior people thinking” (HEI 5).
}

As organisational structure is instrumental to how communication management becomes formally/informally legitimised (see Grandien and Johansson, 2012 Gunter et. al., 2012), restructuring and change often undermine the ability to send out a coherent and uniform message to stakeholders (Barrett, 2002; Cornelissen, 2008; Welch, 2011). Coincidentally, it was felt by many participants that a key reason for pursuing a variety of social agenda-related initiatives was because of ongoing institutional change and restructuring activity:

\footnotetext{
"The University, like many universities in the sector has been going through some turbulence (...) and so consequently a lot of the energies and efforts have been taken up restructuring the University in terms of its faculties, departments and also coming to terms with the financial realities with open enrolment" (HEI 2);

“That's largely to do with institutional changes rather than lack of commitment or anything” (HEI 5).

Thus, a clear discussion thread observed among participants was that there needs to be a longterm resource commitment by HEIs to the social agenda and that this needed to be done through
} greater institutional coordination: 


\footnotetext{
"But the first step is to say we're going to actually going to put some resource, significant resource behind it and we're going to commit to that over a period, so it's not just today or when the Vice-Chancellor leaves the University" (HEI 1A);

“(...) but to actually pin that down and to make it a much more, if you like, institutionalised and prominent feature, you have to get beyond the rhetoric and have to be, you know, we have to be doing even more than we're doing" (HEI 2);

"The University itself needs to coordinate itself a more strategic set of communications over a long period of time with its staff around social value" (HEI 5).
}

As promotion of the social message is seen as being hampered by an institution's restructuring and/or change as well as a disjointed approach (see Thornhill et al., 1996; Varey \& White, 2000; Barratt, 2002), many participants felt that HEIs must act collaboratively to send out a more powerful message: "I think that talking collectively as universities as well is very powerful and something that doesn't happen frequently enough, but, you know, I think it is a very positive thing” (HEI 4). Unsurprisingly, employees urged HEIs to ensure that they 'walk the talk' as so to speak: “And we're in this process of making sure we actually live, you know, the values that we're going to put on the page" (HEI 4).

\section{HEI Communication Practices when Conveying a Social Agenda}

Using a combination of visual stimuli (i.e. SEGM leaflets, Social Impact Reports, Impact video), communications activities were also discussed at length by the participants. However, as social impact appeared not to be widely reported or understood among employees, further sceptical comments were made regarding the contradictory practice of having a social enterprise accreditation such as the SEM, but failing to raise awareness of it due to ineffective communications. For example, P3 held the view that "It's only if people know about it that it has 
any value" (FG P3). Consequently, some participants felt that if it could be demonstrated that an HEI's social values were a unique selling point to attract students, it may be worth investing in:

\footnotetext{
"I think some of the best ways of promoting our image to staff and students is to do good stuff and then make sure they hear about it and that's what we try to do all the time" (HEI 3);

"What we should think about is influence, not just messages and spreading the word, but actual influence and impact, then I think that would be the biggest driver and enabler, you know” (HEI 4).
}

Given Cornelissen's (2008) comments around the implications of ineffective communication and their impact on a lack of buy-in from employees, when talking specifically to co-ordinators of the SEM within the other HEIs, most participants felt that their HEI showed a strong commitment to measuring and reporting on social activity:

\begin{abstract}
"I think we take the kind of social dimension of sustainability perhaps more seriously than other universities might” (HEI 3);
\end{abstract}

"The number of reports that we put in every year that I've just listed to you, that do that, because they're kind of official and, you know, have meaning to the University immediately, because they're going to our regulators" (HEI 4).

However, akin to all employees, it was felt that while plenty of social activity is measured by HEIs, it is still not effectively reported upon: "I mean, there is obviously a social return on investment model, so as long as they are adhering to kind of a national framework, because the problem that I had when I'd seen them was when you, for example, were looking at the value of someone's volunteering, it was very much subjective as what you would relate that to" (HEI 1 $C)$. Moreover, where they do exist, they were observed largely as having little influence:

\footnotetext{
"And I don't see the University investing into social issues or anything that I think they would be able to count coherently in something like a return on social investment model" (HEI IC);

"It's one of those where people just put that in a filing cabinet. It's not a living document that's influencing decisions and informing change at the University" (HEI IC);
} 
Problems in measuring social impact were also listed by participants as a factor for a lack of HEI commitment to social impact reporting: "one of the difficulties is that institutions normally start out by saying "And we want to know what the impact is." What, for us, will be 'impact' and how are we going to measure it?"'(HEI 2). This perception is supported by much of the literature on social impact measurement, which confirms that a lack of quantitative data to analyse social impact makes a comprehensive assessment difficult and infers that it may be largely symbolic as a way of satisfying stakeholders (see Arvidson et al., 2010; Luke et al., 2013).

These reporting limitations are surprising in light of national HEI assessment exercises such as the REF and the forthcoming KEF. Thus, without the commitment and investment into making social impact reports living documents; membership of organisations such as SEM and all social reporting efforts of this kind by HEIs are superficial at best. Interestingly for SEM, all participants felt that any ineffective communications issues did not lie with the SEM promotional materials which are considered to be comprehensive, but rather that there is not always the resource to engage with them fully. Consequently, many suggestions to improve uptake were forthcoming from participants. One participant felt that "there's a conversation that the Company [i.e. the SEM] need to have with existing Mark holders all the time” (HEI 3). Another suggested that there needs to be a financial as well as social incentive for institutions to hold the SEM, for example, "If the Mark has some sort of, I don't know, government backing or regional backing or Local Enterprise Partnership (LEP) backing, whereby there was some sort of subsidy, or something. Some financial advantage as well as social advantage, then that's what good business looks like to me” (HEI 4). Additionally, while SEM champions within HEIs 
would help to promote the message, it was felt by the majority that this was a resource issue which was hard to justify financially:

\footnotetext{
"You can't invest it in champions. You have to be in the DNA of the organisation" (HEI 1A);

"Because everyone's under so much pressure and student recruitment is really tough nowadays. It's a different game and it's all very, very, very aggressive, you know” (HEI 4).
}

Conversations around the enhanced SEGM accreditation also took place, with some participants believing it to be a positive indication of the HEI's strategic direction; whereas others felt that it would only add value if the social agenda becomes more embedded:

\footnotetext{
"The decision came entirely from the Vice-Chancellor. (...) she identified the Social Enterprise Mark as being an important signifier of the direction she wanted the University to go in" (HEI 2);

"I'm not sure what the Gold standard would give us more than we have already in that kind of promotional way” (HEI 3).
}

In addition, one participant argued that the SEGM would need to have greater meaning in terms of ability to trade with others in order to be worthwhile, for example: "So, they've got to get sufficient University Mark holders and then have them agree as a group that they will recognise the Mark in the companies that they trade with and so the Mark will then have value" (HEI 4). This reinforces the views expressed by Ridley-Duff and Southcombe (2012) and Allan (2005) that the SEM needs to offer something different from other accreditations and have recognised value if it is to become embedded by the majority of HEIs. Similarly, participants emphasised how important it is for HEIs to focus on the positive messages when communicating a social agenda: 
"Because no one can really argue with the agenda, because why would you not want to do it? And we are leading in it in certain areas, so, you know, it's a good news story, it's positive” (HEI 1B);

"One of the fears I have is universities become so hard-nosed that they lose sight of many of the social benefits they can give to their employees and to the outside community" (HEI 2).

In moving the social agenda further forward, participants also felt that improved engagement with the social agenda through the SEM accreditation and similar vehicles must be achieved with the student body. Consequently, students were identified as a more effective target than employees as a key stakeholder group for becoming SEM champions and engaging with the social message:

"I would say we need to get better at communicating to potential students what the social enterprise difference is" (HEI 3);

"And I think that is where the push will come from, because all universities now are acutely aware of what it takes to attract students to their courses" (HEI 3);

“(...) obviously the more institutions become engaged with this, the more understood it is, the more likely it is to influence student choices" (HEI 2).

Moreover, if HEIs are more able to overtly express and live their social values and move beyond the corporate image currently projected to both employees and students, there may be a greater opportunity to fully embed the social agenda within HEIs strategies.

\section{Discussion}

Owing to the limited awareness and/or understanding of the SEM from employees, the SEM accreditation for HEIs largely failed to positively influence communication of University A's 
social message to employee stakeholders. Part of this failure was put down to the fact that effective communication in such large institutions such as HEIs is complex, making it difficult to engage with employees. Thus, HEI employees tended to carry out their own localised social activities and get involved with institutional-level initiatives that are relevant to their own roles, partially owing to workload and pressures on time. In some cases, employees also felt as if they were being coerced to adopt a social agenda (see Figure 1). This in itself, makes it clear that the SEM and/or social agenda is not considered a priority for HEIs, although if a more cohesive and coherent communications strategy were put into place, there could potentially be greater employee buy-in (see Figure 2). For example, giving employees' time in lieu at work to undertake social enterprise-related activities (e.g. increased collaboration with enterprises around placements, internships; or Knowledge Teaching Partnerships) may encourage greater engagement, as well as providing quantifiable data for measuring social impact. There is also significant potential for the SEM personnel to assist HEIs in producing clear guidelines around their role as social enterprises and around the criteria that is being assessed. Indeed, without such toolkits, the effectiveness of the SEM will remain a tokenistic badge for HEIs as well as fail to convince stakeholders of their commitment to a social agenda.

Insert Figures 1 and 2 near here

The thematic networks generated from the focus groups findings interconnected well with the themes that emerged from the HEI depth interviews. These were conducted with HEI 
SEM/SEGM holders in order to explore and compare the way in which the SEM accreditation is used by HEIs to communicate a social message (see Figure 4). Here, our findings identified a greater need for HEIs to demonstrate their social values more overtly in order to prove the importance of the social agenda to senior management. Although HEI mission statements profess commitment to a social agenda, many are guilty of mission drift and do not effectively live these values at present. The existing literature also suggests that HEIs have not yet fully addressed this shift towards a more explicit commitment to the social agenda (see Djordjevic \& Cotton, 2011; Lozano, 2011) and this study's findings support this commonly held view. Overall, these findings have been able to offer greater theoretical insight into an under-researched area of the literature, namely employee engagement (see Welch, 2011) with the social agenda and also to link this to another less developed area around communication in HEIs (see Djordjevic \& Cotton, 2011) around social enterprise (British Council, 2016).

\section{Conclusions, Limitations and Avenues for future Research}

This study set out to explore in the context of University A, whether the SEM accreditation provides HEIs with a tool to positively influence communication of their social message to stakeholders. This involved exploring employee views about how social messages are conveyed and promoted at the University and to ascertain how effectively University A's internal communication mechanisms functioned in engaging with employees compared to other HEIs who held the SEM/SEGM. Visual stimuli in the form of SEM/SEGM leaflets, promotional materials and University A's social and economic impact report/video, helped to facilitate an insightful debate around the value of the SEM for HEIs. 
In conclusion, this study has responded to calls for a greater understanding of marketing activities within social enterprise (see Powell \& Osborne) and provided theoretical insight into an under-researched area of the literature, namely employee engagement (see Welch, 2011) with the social agenda and more specifically the marketing role of the SEM accreditation. Moreover, we also contribute to the less developed area around communication in HEIs (see Djordjevic \& Cotton, 2011) around social enterprise (British Council, 2016), especially regarding whether the SEM positively influences stakeholders or merely pays lip service to HEI commitment to a social agenda.

While it was acknowledged by participants that the SEM offers a means of publically displaying an institution's commitment to the social agenda, our findings reveal that in many cases, HEIs are merely paying lip service to their social commitment and the SEM could be considered 'just another badge' (i.e. akin to greenwashing). Similarly, it was felt by a number of HEIs that the SEGM currently has no meaningful impact as an enhanced accreditation because it is unable to provide added value or a financial incentive such as preferential trading arrangements, for example. As such, it is difficult to make a case to senior management for making the SEM accreditation and/or the pursuit of a social agenda a priority over other competing economic and/or market demands in a way that would provide competitive advantage. This indicates a need for a stronger narrative around social values in order to better articulate this, for example by reframing economic objectives as social objectives.

It also emerged that employee engagement was not considered the most effective way to improve communication of the social message and that instead the student body should be targeted. Students are the core business of HEIs and therefore, achieving their buy-in towards the 
social message would be a step in the right direction in embedding a social agenda within institutional strategy, if it could be demonstrated that attending a socially responsible institution would be a factor in making their future study choices. HEIs have a responsibility to remain true to their mission statement and seek to fulfil their social mission beyond tokenistic acquisitions of accreditations if they are to engage stakeholders with a social agenda. This is an emerging topic in the management literature in relation to PRME and the citizenship agenda and warrants further research to ascertain its impact on student choice (see also Arac \& Madran, 2014).

However, this study is not without its limitations, especially in the area of reaching theoretical saturation. At the time of this study, fewer SEM accredited HEIs existed and therefore, the above conclusions are based upon a small select sample of HEIs that held the SEM. However, the use of purposive sampling employed in this study is one means of accommodating generalisability issues (Patton, 2002; Silverman, 2013), given that the participants were deliberately selected from areas in which the processes studied were most likely to occur. Nonetheless, further studies are needed to provide a more representative view of each University's use of and commitment to the SEM/SEGM.

In order to achieve institutional buy-in for the social message and the SEM accreditation in particular, further impactful research should be carried out to investigate the additional benefits that the accreditation can bring, both financially and socially. Finally, although this study focuses on the social message, it is important to recognise that the SEM accreditation also refers to an organisation's environmental impact. Therefore, given the increasing role of the $\mathrm{REF} / \mathrm{KEF}$ and its growing emphasis on demonstrating research impact, it is crucial that HEIs are able to more adequately and effectively report on social impact through means of external audits 
and/or Social Return on Investment based models. This would encourage stakeholders to take the social agenda more seriously in the future. 


\section{References}

Allan, B. (2005). Social enterprise: through the eyes of the consumer (prepared for the National Consumer Council). Social Enterprise Journal, 1(1), 57-77.

Arac, S.K., \& Madran, C. (2014). Business school as an initiator of the transformation to sustainability: A content analysis for business schools in PRME. Social Business, 4(2), 137152. Doi: 10.1362/204440814X14024779688115.

Arvidson, M., Lyon, F., McKay, S., \& Moro, D. (2010). The Ambitions and Challenges of SROI. Third Sector Research Centre Working Paper 49. Retrieved 31 October, 2016 from http://www.birmingham.ac.uk/generic/tsrc/index.aspx.

Ashoka (2018). What is Ashoka? Retrieved 20 April, 2018 from https://www.ashoka.org/en/story/what-ashoka.

Attride-Sterling, J. (2001). Thematic networks: an analytic tool for qualitative research. Qualitative Research, 1(3), 385-405.

Barrett, D.J. (2002). Change communication: using strategic employee communication to facilitate major change. Corporate Communications: An International Journal, 7(4), 219-231. Doi: $10.1108 / 13563280210449804$.

Braun, V., \& Clarke, V. (2006). Using thematic analysis in psychology. Qualitative Research in Psychology, 3(2), 77-101. Doi: 10.1191/1478088706qp063oa.

British Council. (2016). Social Enterprise In a Global Context. Retrieved 14 September, 2016 from https://www.britishcouncil.org/education/ihe/knowledge-centre/partnershipscollaboration/report-social-enterprise-global-context.

Brown, M.D. (2015). Tendering for a social cause: universities and social enterprise. Social Alternatives, 34(2), 27-32.

Ceulemans, K., Molderez, I., \& Van Liedekerke, L. (2015). Sustainability reporting in higher education: a comprehensive review of the recent literature and paths for further research. Journal of Cleaner Production, 106, 127-143. Doi: 10.1016/j.jclepro.2014.09.052.

Cornelissen, J. (2004). Corporate Communications. London: Sage Publications Ltd.

Cornelissen, J. (2008). Corporate Communication: Guide to Theory and Practice. London: Sage Publications Ltd.

Defourny, J., \& Nyssens, M. (2008). Social enterprise in Europe: recent trends and developments. Social Enterprise Journal, 4(3), 202-228, Doi.org/10.1108/17508610810922703. 
Djordjevic, A., \& Cotton, D.R.E. (2011). Communicating the sustainability message in higher education institutions. International Journal of Sustainability in Higher Education, 12(4), 381-394. Doi:10.1108/14676371111168296.

Doherty, B., Haugh, H. \& Lyon, F. (2014). Social enterprises as hybrid organisations: A review and research agenda. International Journal of Management Reviews, 16(4), 1-20.

Di Domenico, M., Tracey, P., \& Haugh, H. (2009). The dialectic of social exchange: Theorizing corporate - social enterprise collaboration. Organization studies, 30(8), 887-907. Doi.org/10.1177/0170840609334954.

Easterby-Smith, M., Thorpe, R., \& Lowe, A. (2002). Management Research: An Introduction (2nd ed.). London: Sage Publications Ltd.

Galera, G., \& Borzaga, C. (2009). Social enterprise: An international overview of its conceptual evolution and legal implementation. Social enterprise journal, 5(3), 210-228. doi.org/10.1108/17508610911004313

Goodman, M. (1994). Corporate Communication: Theory and Practice. Albany: State University of New York Press.

Grandien, C., \& Johansson, C. (2012). Institutionalization of communication management. Corporate Communications: An International Journal, 17(2), 209-227. Doi: $10.1108 / 13563281211220247$.

Gunter, H.M., White, J., \& Fitzgerald, T. (2012). Hard labour? Academic Work and the Changing Landscape of Higher Education. Bingley: Emerald Group Publishing Limited.

Haugh, H. (2005). A research agenda for social entrepreneurship. Social Enterprise Journal, 1(1), 1-12, Doi.org/10.1108/17508610580000703.

Hoefer, R.A., \& Sliva, S.M. (2016). Social enterprise in higher education: a viable venture? Journal of Social Work Education, 52(4), 422-433. Doi:10.1080/10437797.2016.1165156.

Kantanen, H. (2012). Identity, image and stakeholder dialogue. Corporate Communications: An International Journal, 17(1), 56-72. Doi: 10.1108/13563281211196353.

Kay, A., Roy, M.J. \& Donaldson, C. (2016). Re-imagining social enterprise. Social Enterprise Journal, 12(2), 217-234, Doi.org/10.1108/SEJ-05-2016-0018.

Kickul, J., \& Lyons, T. (2012). Understanding Social Entrepreneurship: The Relentless Pursuit of Mission in an Ever Changing World. London: Routledge.

Kozinets, R., Fischer, E., \& Belk, R. (2013). Qualitative consumer and marketing research. London: Sage Publications Ltd. 
Lozano, R. (2011). The state of sustainability reporting in universities. International Journal of Sustainability in Higher Education, 12(1), 67-78. Doi: 10.1108/14676371111098311.

Lozano, R., Ceulemans, K., Alonso-Almeida, M., Huisingh, D., Lozano, F., Waas, T., Lambrechts, W., Lukman, R., \& Hugé, J. (2015). A review of commitment and implementation of sustainable development in higher education: results from a worldwide survey. Journal of Cleaner Production, 108, 1-18. Doi: 10.1016/j.jclepro.2014.09.048.

Luke, B., Barraket, J., \& Eversole, R. (2013). Measurement as legitimacy versus legitimacy of measures. Qualitative Research in Accounting \& Management, 10(3/4), 234-258. Doi: 10.1108/QRAM-08-2012-0034.

Melewar, T.C., \& Akel, S. (2005). The role of corporate identity in the higher education sector. Corporate Communications: An International Journal, 10(1), 41-57. Doi: $10.1108 / 13563280510578196$.

Mannion, L. (2016). UnLtd bets on HEIs to take social entrepreneurship mainstream. Pioneers Post. Retrieved 29 April, 2016 from https://www.pioneerspost.com/newsviews/20160429/unltd-bet-on-heis-take-social-entrepreneurship-mainstream?

Mauksch, S., Dey, P., Rowe, M., \& Teasdale, S. (2017). Ethnographies of social enterprise. Social Enterprise Journal, 13(02), 114-127. doi.org/10.1108/SEJ-03-2017-0019

Moody, M., Littlepage, L., \& Paydar, N. (2015). Measuring social return on investment. Nonprofit Management \& Leadership, 26(1), 19-37. doi: 10.1002/nml.21145

Murray, R., Caulier-Grice, J. \& Mulgan, G. (2010). The open book of social innovation. Retrieved 31 October, 2016 from http://www.nesta.org.uk/sites/default/files/the_open_book_of_social_innovation.pdf

Patton, M.Q. (2002). Qualitative Research and Evaluation Methods (3rd Ed.). London: Sage Publications Ltd.

Peattie, K., \& Adrian Morley, (2008) Eight paradoxes of the social enterprise research agenda, Social Enterprise Journal, 4(2), 91-107. Doi.org/10.1108/17508610810901995.

Perez de Mendiguren Castresana, J.C. (2013). Social enterprise in the development agenda. Opening a new road map or just a new vehicle to travel the same route? Social Enterprise Journal, 9(3), 247-268. Doi.org/10.1108/SEJ-07-2012-0021.

PRME (2018) What is PRME? Retrieved 20 April, 2018 from http://www.unprme.org/about-prme/index.php

Powell, M., \& Osborne, S.P. (2015), Can marketing contribute to sustainable social enterprise?, Social Enterprise Journal, 11(1), 24-46. Doi:10.1108/SEJ-01-2014-0009. 
Ridley-Duff, R., \& Bull, M. (2016). Understanding Social Enterprise: Theory and Practice (2nd Ed.). London: Sage Publications Ltd.

Ridley-Duff, R., \& Southcombe, C. (2012). The Social Enterprise Mark: a critical review of its conceptual dimensions. Social Enterprise Journal, 8(3), 178-200. Doi: 10.1108/17508611211280746.

Schmeltz, L. (2012). Consumer-oriented CSR communication: focusing on ability or morality? Corporate Communications: An International Journal, 17(1), 29-49. Doi: $\underline{10.1108 / 13563281211195344 .}$

SEUK. (2017). Social Enterprise UK. Retrieved 28 February, 2017 from http://www.socialenterprise.org.uk/

Shriberg, M. (2002). Institutional assessment tools for sustainability in higher education. International Journal of Sustainability in Higher Education, 3(3), 254-270. Doi: $10.1108 / 14676370210434714$.

Silverman, D. (2011). Interpreting Qualitative Data: A Guide To The Principles of Qualitative Research (4th Ed.). London: Sage Publications Ltd.

Silverman, D. (2013). Doing Qualitative Research (4th Ed.). London: Sage Publications Ltd.

Social Enterprise Mark. (2018). Social Enterprise Mark. Retrieved 20th March, 2018 from http://www.socialenterprisemark.org.uk/

Teasdale, S. (2010). What's in a name? The construction of social enterprise. $6^{\text {th }}$ September. Third Sector Research Centre, Working Paper 46.

Thompson, J. (2011). Reflections on social enterprise and the Big Society. Social Enterprise Journal, 7(3), 219-223. Doi: 10.1108/17508611111182377.

Thornhill, A., Lewis, P., \& Saunders, M.N.K. (1996). The role of employee communication in achieving commitment and quality in higher education. Quality Assurance in Education, 4(1), 12-20. Doi: 10.1108/09684889610107995.

Too, L., \& Bajracharya, B. (2015). Sustainable campus: engaging the community in sustainability. International Journal of Sustainability in Higher Education, 16(1), 57-71. Doi: 10.1108/IJSHE-07-2013-0080.

Varey, R.J., \& White, J. (2000). The corporate communication system of managing. Corporate Communications: An International Journal, 5(1), 5-12. Doi: 10.1108/13563280010317523.

Welch, M. (2011). The evolution of the employee engagement concept: communication implications. Corporate Communications: An International Journal, 16(4), 328-346. Doi: $10.1108 / 13563281111186968$. 
Wengraf, T. (2001). Qualitative Research Interviewing: Biographic Narrative And SemiStructured Methods. London: Sage Publications Ltd.

Westall, A. (2009). Business or third sector? What are the dimensions and implications of researching and conceptualising the overlap between business and third sector. December. Third Sector Research Centre, Working Paper 26.

Winn, J. (2015). The co-operative university: Labour, property and pedagogy. Power and Education, 7(1), 39-55. doi.org/10.1177/1757743814567386 


\section{Table 1 Example of Thematic Analysis}

\section{Stage 1}

\begin{tabular}{|c|c|c|}
\hline $\begin{array}{l}\text { CODES } \\
\text { (SPECIFIC TOPICS) }\end{array}$ & ISSUES DISCUSSED & THEMES IDENTIFIED \\
\hline $\begin{array}{l}\text { - Social agenda } \\
\text { - Links with communities } \\
\text { - Institutional engagement }\end{array}$ & $\begin{array}{l}\text { - Lip service } \\
\text { - Responsibility as employer } \\
\text { - } \text { Driving economic policy } \\
\text { - Lack of resources } \\
\text { - Lack of commitment } \\
\text { - Disjointed strategy } \\
\text { - Separate social agendas } \\
\text { - Focus on core business } \\
\text { - Not strategic priority } \\
\text { - Community-minded } \\
\text { - Core social values } \\
\text { - Social mobility } \\
\text { - Linking CSR agendas } \\
\text { - USP to attract funders } \\
\text { - High-level research } \\
\text { - Senior buy-in } \\
\text { - Student recruitment }\end{array}$ & $\begin{array}{l}\text { 1. There is a lack of commitment } \\
\text { from HEIs towards the social } \\
\text { agenda } \\
\text { 2. Social and environmental } \\
\text { strategy is disjointed and lacks } \\
\text { direction } \\
\text { 3. HEIs focus on core business and } \\
\text { financial priorities } \\
\text { 4. HEIs are community-minded } \\
\text { with social values at their core } \\
\text { 5. Greater research is required to } \\
\text { improve social engagement }\end{array}$ \\
\hline
\end{tabular}

Stage 2

THEMES AS BASIC THEMES
1. There is a lack of commitment
from HEIs towards the social
agenda
2. Social and environmental
strategy is disjointed and lacks
direction
3. HEIs focus on core business and
financial priorities
4. HEIs are community-minded
with social values at their core
5. Greater research is required to
improve social engagement

\section{ORGANISING THEMES}

Social agenda not a strategic priority

HEIs must overtly demonstrate social core

\section{GLOBAL THEMES}

HEI communication of social values 
Table 2 Key Informant Descriptors

\begin{tabular}{|c|c|c|}
\hline $\begin{array}{l}\text { Key-Informant } \\
\text { Descriptor }\end{array}$ & $\begin{array}{c}\text { Method of } \\
\text { Data Collection }\end{array}$ & SEM Membership Status* \\
\hline HEI 1 FG P1 & $\begin{array}{l}\text { Focus Group (face-to-face) } \\
\text { Participant } 1\end{array}$ & University A/SEGM \\
\hline HEI 1 FG P2 & $\begin{array}{c}\text { Focus Group (face-to-face) } \\
\text { Participant } 2\end{array}$ & University A/SEGM \\
\hline HEI 1 FG P3 & $\begin{array}{c}\text { Focus Group (face-to-face) } \\
\text { Participant } 3\end{array}$ & University A/SEGM \\
\hline HEI 1 FG P4 & $\begin{array}{c}\text { Focus Group (face-to-face) } \\
\text { Participant } 4\end{array}$ & University A/SEGM \\
\hline HEI 1 FG P5 & $\begin{array}{c}\text { Focus Group (face-to-face) } \\
\text { Participant } 5\end{array}$ & University A/SEGM \\
\hline HEI 1 FG P6 & $\begin{array}{c}\text { Focus Group (face-to-face) } \\
\text { Participant } 6\end{array}$ & University A/SEGM \\
\hline HEI 1 A & HEI Interview (face-to-face) & University A/SEGM \\
\hline HEI 1 B & HEI Interview (face-to-face) & University A/SEGM \\
\hline HEI $1 \mathrm{C}$ & HEI Interview (face-to-face) & University A/SEGM \\
\hline HEI 2 & HEI Interview (telephone) & University B/SEGM \\
\hline HEI 3 & HEI Interview (telephone) & University $\mathrm{C} / \mathrm{SEM}$ \\
\hline HEI 4 & HEI Interview (telephone) & University D/SEM \\
\hline HEI 5 & HEI Interview (telephone) & University E/SEM \\
\hline
\end{tabular}

*Membership status of each University refers to at the time of the data collection. 


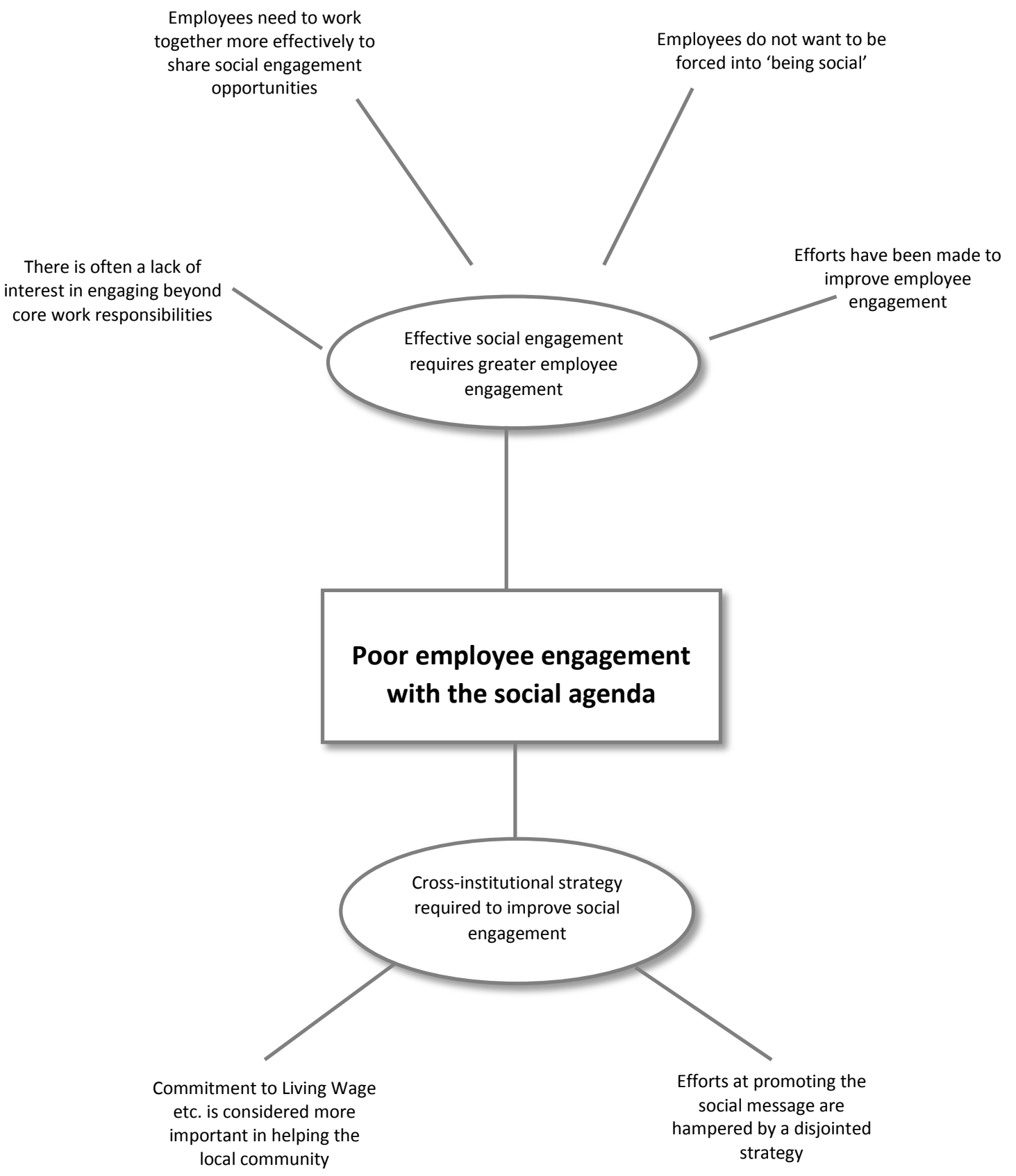


Figure 2

\section{Thematic Network Around Senior Management Buy-In}

There needs to be greater institutional coordination to embed the social agenda

There needs to be a longterm resource commitment by HEls to the social agenda

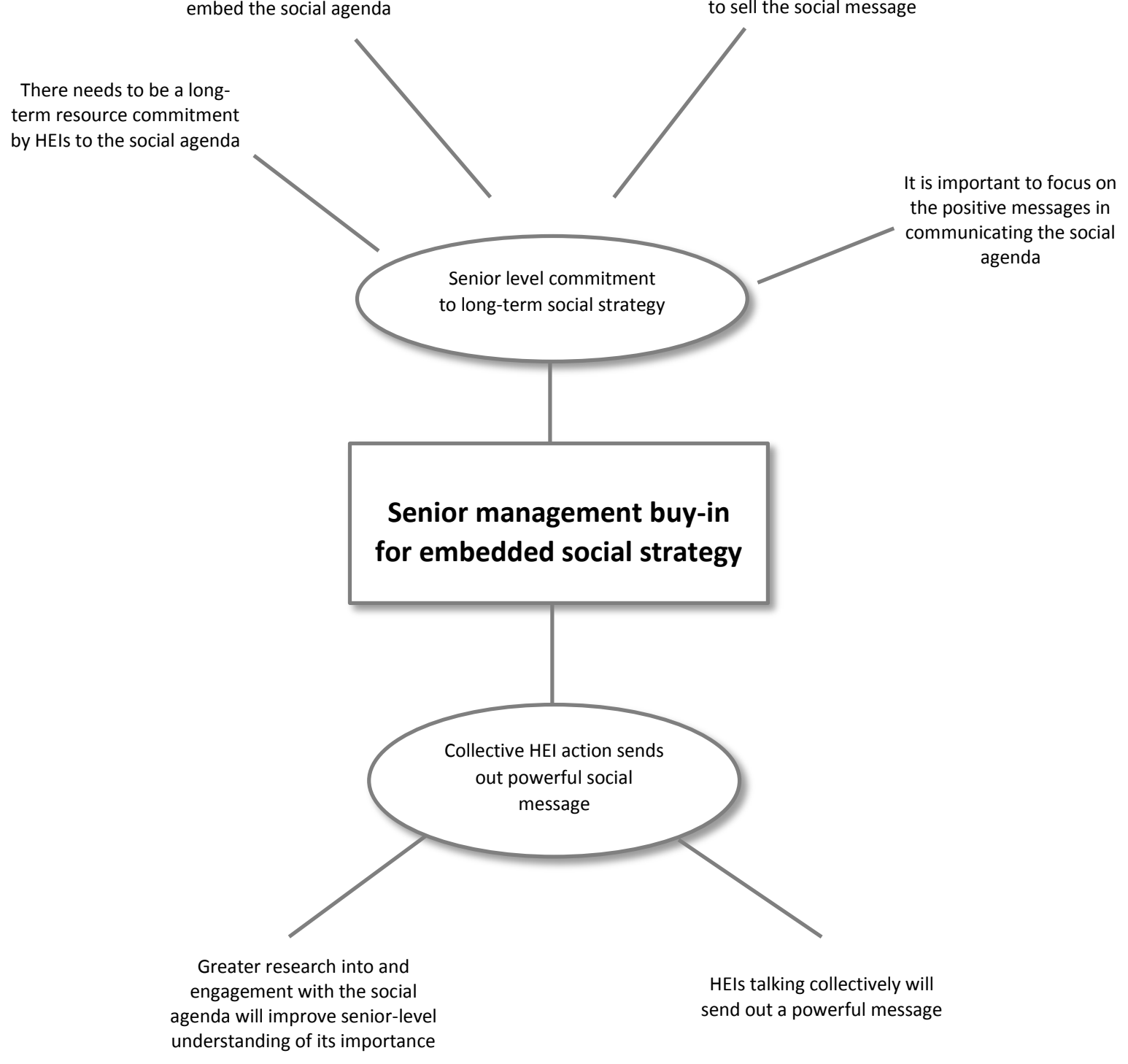

Preferential arrangements with other SEM holders would help to sell the social message 